\title{
Hairy Cell Leukemia
}

National Cancer Institute

\section{Source}

National Cancer Institute. Hairy Cell Leukemia. NCI Thesaurus. Code C7402.

A neoplasm of small B-lymphocytes with "hairy" projections in bone marrow, spleen, and peripheral blood. Most patients present with splenomegaly and pancytopenia. (WHO, 2001) 